1.はじめに

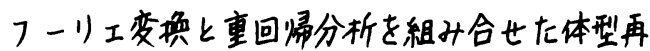
生のアルゴリズムを考察し，身長，体重，胸囲な どの数個の身体計測値力う任意の㑑体の体型形状 を丒生した。表示には，コンピュータ・グラフィ ック・ディスプレイ Core System / SIGGRAPH GSPCを用い，立体㮏視変涣，除線処理によっ? 縦横の曲緗力らなる人体幾可学トルソモジルを棈 成した。

\section{2. 方 法}

1) スライディング・ゲージにdる形熊計测 体型㖕制用に試作したスライディング・ゲージ を用い，上腕大結飾の高さを基蕉に，腹部に至る 11 㑑の实测楼断面输郭曲線を計测した。被倹者は 20歳代から30代の健常男子計20名である。

2) 二次元フーリ工解析

得られた楼断面輪部曲線をA/D变㛟し，その デー夕を二次元高速フーリ工变埆（FFT）し， 解析した。きず，有限複素フーリ工係数さ求め， 兰れを用いてフーリエ运变埃から实测模断面输部 を充分に近似できろフーリェ成分数を求めた。

\section{3）主回燸分析}

各断面ざとのフーリエ係数(实数部々虚数部) ○へキ8次フーリ工成分を9毫類の身体計测值， するれち身長，体重，胸团，殿团，有幅，腰田， 胸厚，胸幅，腹厚上の重回㷌分析を行よった。

4) 三次元再生像の算出およで表示

各川断面ざとのk次7ーリ工伱数推定值を，被 姶者20名分の身体計測値の玄一多行列V と，偏回 懦你数 $\beta$ により算出し，光の推定值 $C x(k), C y(k)$ をつ一リ工変涣式に代入し，推定槽断面輪郭を再 生した。次いで首输部を含む各断面间を緗形補间

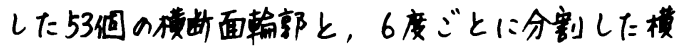

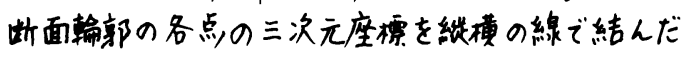
人体トルソモデルを模成した。

体型三次元再生のアルゴリズムおよで各变煥式 を示した（因1，2，3）。

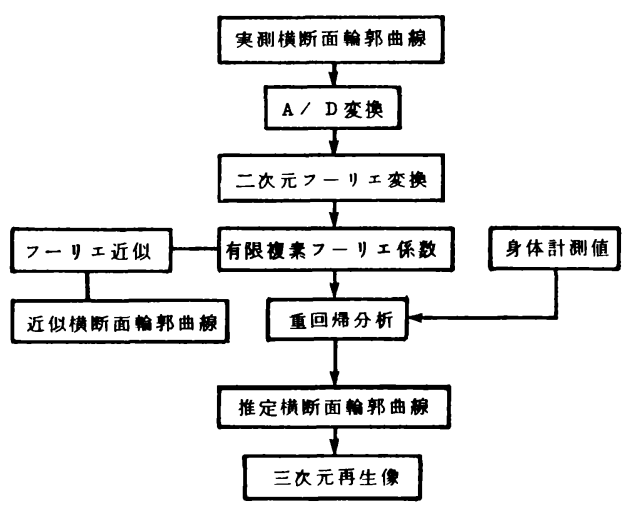

因1、体型三次元再生のアルゴリズム

$$
\begin{aligned}
& C_{(k)}=\frac{1}{N} \sum_{m=0}^{N-1} X m \exp \left\{-\frac{2 \pi i k m}{N}\right\} \\
& C y(k)=\frac{1}{N} \sum_{m=0}^{N-1} Y m \exp \left\{-\frac{2 \pi i k m}{N}\right\} \\
&(k=0,1,2, \ldots, N-1) \\
& X m= \sum_{k=0}^{N-1} C x(k) \exp \left\{\frac{2 \pi i k m}{N}\right\} \\
& Y m= \sum_{k=0}^{N-1} C y(k) \exp \left\{\frac{2 \pi i k m}{N}\right\} \\
&(m=0,1,2, \ldots, N-1)
\end{aligned}
$$

因2、楼断面体型近似のためのフーリ工变换式

$$
\begin{aligned}
& \left\{\begin{array}{l}
\hat{C X}(k)=v B+\varepsilon \\
\hat{C Y}(k)=v B+\varepsilon
\end{array}\right. \\
& \hat{C x}(k): k \text { 次フーリエ成分推定 } \\
& \mathrm{v} \text { : 身体計測値のテータ行列 } \\
& \text { B : 偏回㷌保数 } \\
& \varepsilon \text { : 残差 } \\
& \begin{array}{l}
\hat{\mathrm{X}} \mathrm{m}=\sum_{\mathbf{k}=0}^{\mathrm{N}-1} \hat{\mathrm{Cx}}(\mathbf{k}) \exp \left\{\frac{2 \pi i \mathrm{~km}}{\mathrm{~N}}\right\} \\
\hat{\mathrm{Y}}_{\mathrm{m}}=\sum_{\mathbf{k}=0}^{\mathrm{N}-1} \hat{\mathrm{CY}}(\mathbf{k}) \exp \left\{\frac{2 \pi i \mathrm{~km}}{\mathrm{~N}}\right\}
\end{array}
\end{aligned}
$$

四3。体型三次元再生のkのの重回樟式と フーリ工变换式 
3 . 結果

1) 体型（A）の三次元再生像（因4）

右侧に实体型の三次元像を示し，下部に之れぞ 水4次，6次，8次きでのフーリ工成分教で推定 再生しに三次元像を示す。投影点 $(\mathrm{cm})(x$ ， $y, z)$ は $(0,100,-100)$ である。

(体型 A：身長 $180 \mathrm{~cm}$ ，体重 $66 \mathrm{~kg}$ ，胸困 $89 \mathrm{~cm}$ ，殿 国91 cm，肩幅 $46 \mathrm{~cm}$ ，腰团 $73 \mathrm{~cm}$ ，胸厚20.5 cm，胸幅 $32.0 \mathrm{~cm}$ ，腹厚 $23.0 \mathrm{~cm})$.
因4。

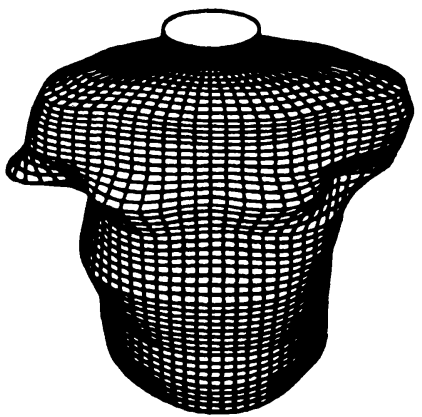

\section{ESTIMATED}

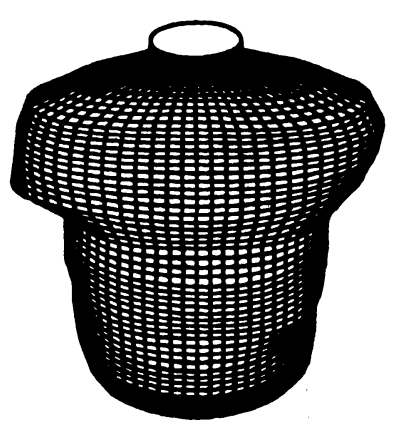

4 COMPONENTS

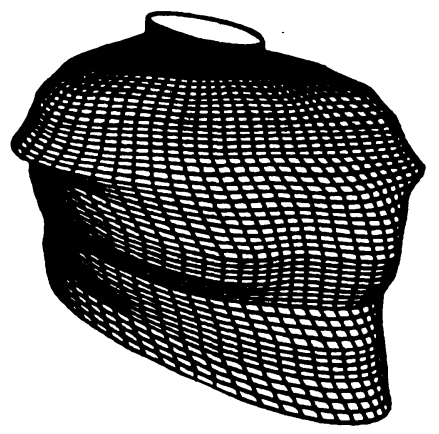

因5、肥清体型の三次元再生像

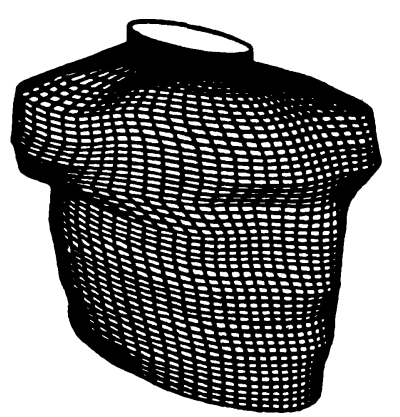

四6.細身体型の三次元再生像

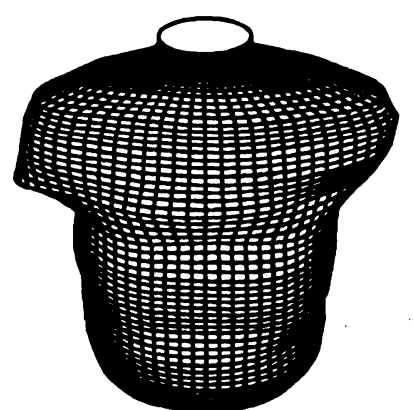

6 COMPONENTS

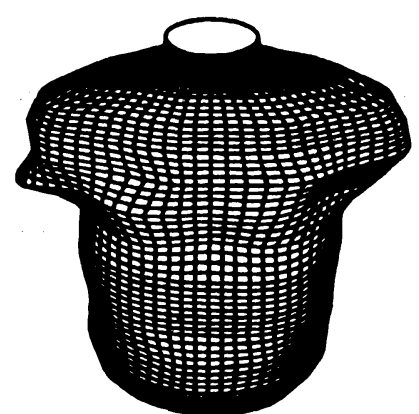

8 COMPONENTS
2)肥满体型（B）およで細身体型

(c) での三次元再生像（园5.6) 右倒が8次成分での推定再生像。 投影点(cm)は $(-100,100,-100)$. （体型 B：身長172 cm，体重79 kg，胸 团 $96 \mathrm{~cm}$ ，殿国92 cm，肩幅46cm，腾围 $88 \mathrm{~cm}$ ，胸厚 $22.0 \mathrm{~cm}$ ，胸幅 $37.5 \mathrm{~cm}$ ，腹 厚 $27.0 \mathrm{~cm}$ ) (体型 C：身長 $162 \mathrm{~cm}$ ， 体重49 kg，胸国81 cm，殿国82 cm， 肩幅 $43 \mathrm{~cm}$ ，腰囲 $72 \mathrm{~cm}$ ，胸厚 $16.5 \mathrm{~cm}$ ， 胸幅 $28.0(\mathrm{~cm}$ ，儤厚 $18.0 \mathrm{~cm})$ 。

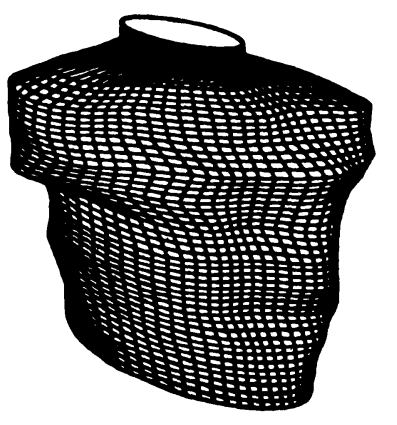

ESTIMATED

\section{4. 考察}

胸部三次元像を再生する绦，フー リ工成分数が增加するにつれて，体 型の近似度が良くてることが礁鼠で き，成分数は8次までが必要であろ。 㓌絙消去，透梘变埃によ体型の 表现栰能が向上した。

本手法は，人体の形能学的研究， 人体形状の定量化に有初である七思 われる。 